\title{
Evaluación electromiográfica de los músculos masticadores durante la fuerza máxima de mordedura
}

\section{Electromyography Evaluations of the masticator muscles during the maximum bite force}

\author{
M.J.P. Coelho-Ferraz¹ , F. Bérzin², C. Amorim³
}

Resumen: La actividad de los músculos masetero y de la porción anterior temporal de ambos lados, derecho e izquierdo, respectivamente, durante la fuerza máxima de mordedura fue estudiada en voluntarios sanos. El estudio incluyó a 17 voluntarios adultos de ambos sexos, edad promedia de 25 años, que no evidenciaban ningún indicio de disfunción temporomandibular y eran relacionados con la Facultad de Odontología de Piracicaba. Se registraron los datos electromiográficos en ambos lados de la cara del masetero y de la porción anterior de los músculos temporal y suprahioideo en las posiciones postural e isométrica. Se utilizaron electrodos de superficie pasivos para niños, de $\mathrm{Ag} / \mathrm{AgCl}$, con forma circular y descargables de MeditraCe $®$ Kendall-LTP, modelo Chicopee MA01. Éstos se conectaron a un preamplificador con una ganancia de $20 x$ que formaba un circuito de diferenciales. Se captaron los registros de las señales eléctricas utilizando un equipo EMG-8OOC de EMG System of Brazil, Ltd., de ocho canales, a una frecuencia de $2 \mathrm{KHz}$ con 16 bitios de resolución y un filtro digital con un paso de banda de 20 a 500Hz. Se utilizó también un transductor de presión que consistía en un tubo de goma con un sensor de presión $($ MPX 5700)* (Motorola SPS, Austin, TX, EE.UU.) para registrar la fuerza máxima de mordedura. El análisis estadístico incluyó la correlación lineal, la prueba t emparejada y el análisis de la varianza. Se consideró estadísticamente significativa una probabilidad de $p<0,05$. Los resultados pusieron en evidencia cierto grado de asimetría muscular para el masetero y la porción anterior del músculo temporal que variaba en relación con la tarea realizada y la intensidad de la contracción. El índice de asimetría fue menor en la posición postural que en la de fuerza máxima de mordedura.

Palabras clave: Electromiografía; Biomecánica mandibular.

Recibido: 22.9 .08

Aceptado: 20.11 .08
Abstract: Healthy individuals were examined in terms of the pattern of activity of the masseter and temporal muscles in their anterior portion of both right and left sides, respectively, with the maximum bite force. The study consisted in seventeen adult volunteers with no sign of apparent temporomandibular dysfunction, of both genders, connected to the School of Dentistry of Piracicaba, with average age of 25 years old. The electromyography data were obtained, bilaterally, of the masseter, anterior portion of temporal and suprahyoid muscles in the postural and isometric positions. Were utilized surface passive electrodes for kids of $\mathrm{Ag} / \mathrm{AgCl}$, of circular format and dischargeable of Meditrace ${ }^{\circledR}$ Kendall-LTP, model Chicopee MA01, attached to a pre-amplifier with gain of 20 times forming a differential circuit. The records of the electrical signs were captured by the equipment EMG-800C of EMG System of Brazil $L t d$. of eight channels, with frequency of $2 \mathrm{KHz}$ and 16 bits of resolution, digital filter with band pass of 20 to $500 \mathrm{~Hz}$. It was utilized also a pressurized transductor which consists of a pressurized rubber tube connected to a sensor element (MPX 5700) to obtain the maximum bite force. The statistic tests used were linear correlation, test $t$ in pair and analysis of variance. Probability of $p<0,05$ were significant considered statistically. The results showed a certain degree of muscular asymmetry for the masseter and anterior portion of temporal muscles that depended on the task performed or contraction level. The index of asymmetry was lower in the postural position than in the maximum bite force.

Key words: Electromyography; Mandibular biomechanics.

\footnotetext{
1 Professor, Department of Orthodontics, Uniararas School, Araras, São Paulo, Brasil.

2 Fausto Bérzin. Professor and Department Chair, Department of Morphology, Piracicaba Dental School, UNICAMP, São Paulo, Brasil.

3 Cesar Amorim. Engineering, São José dos Campos, São Paulo, Brasil.
}

\section{Correspondencia:}

Maria Julia P. Coelho-Ferraz

Alameda João Senra, 148

Colinas de São João

Limeira - SP, Brasil

13481-299

e-mail: mjcoelhoferraz@hotmail.com 


\section{Introducción}

La dinámica maxilar ha sido el tema de numerosas investigaciones científicas y hay muchos aspectos de la biomecánica que aún no se entienden completamente. El patrón de actividad de los músculos masticadores durante la apertura máxima de la boca depende de ciertos factores oclusales (Helkimo y cols., 1977), el contactos prematuro (Bakke y Moller, 1980), la morfología facial, la fuerza muscular general y diferencias entre los sexos (Killiaridis y cols., 1995), además de la fase de la dentadura, localización de la fuerza de mordedura, aspectos emocionales del paciente, actitudes del investigador y del paciente, las señales y los síntomas de disfunción temporomandibular (Fields y cols., 1986; Bakke y cols., 1990).

La medición de la fuerza máxima de mordedura es un intento de cuantificar la fuerza total de los músculos que intervienen en el cierre mandibular (Wang y cols., 1990). Castro Folio y cols. (2005) han concluido que las variables de la electromiografía de superficie medidas durante la contracción isométrica de los músculos mandibulares elevadores y el registro de la fuerza de mordedura tienen una buena reproducibilidad en el uso clínico. Han resaltado la importancia de conocer que, durante la recepción de la carga a la izquierda y la derecha durante la abertura y cierre de la mandíbula en el curso de la mordedura isométrica, la cabeza de la mandíbula del lado de balanceo recibe una mayor carga promedia que la cabeza de la mandíbula del lado de trabajo. Esta diferencia depende del patrón de reclutamiento muscular (si el punto de mordedura permanece constante) y de las características mecánicas del alimento (Hylander, 1975, 1977, 1985).

El objetivo de este estudio fue examinar, en individuos considerados sanos, el patrón de actividad del masetero y de la porción anterior del temporal de ambos lados, izquierdo y derecho, respectivamente, durante la aplicación de la fuerza máxima de mordedura.

\section{Material y Método}

Para el estudio fueron seleccionados 17 voluntarios de los dos sexos relacionados con la Facultad de Odontología de Piracicaba, cuya edad media era de 25 años. El trabajo actual comenzó tras obtener la autorización del Comité Ético de Investigación con Seres Humanos (CEP) de FOP-UNICAMP, según las disposiciones de la resolución 196/96 de la Comisión Nacional de Ética en la Investigación (CONEP) del Consejo Nacional de Salud. Para seleccionar la muestra del estudio actual, los criterios fueron: relación dental Clase I de Angle y dentadura permanente, ausencia de tratamiento funcional ortodóntico y/o ortopédico sobre el maxilar en los 10 años previos, ausencia de caries importantes y ausencia de indicios o síntomas de trastornos de la masticación.

Se grabaron los registros electromiográficos del músculo masetero y de la porción anterior del músculo temporal. Se utilizó un electromiografo EMG-800C de EMG System of Brazil, Ltd., de ocho canales, con cinco bandas de ganancia de amplificación, rechazo del modo común $>120 \mathrm{~dB}$, convertidor analógico-digital (A/D) de 16 bitios de resolución de la banda dinámica, que estaba conec-

\section{Introduction}

The jaw dynamics has been the focus of many scientific investigations and many aspects of biomechanics are not fully understood. The pattern of the activities of the masticator muscles during the maximum aperture depends on some occlusal factors (Helkimo et al., 1977), premature contacts (Bakke \& Moller, 1980), facial morphology, general muscular strength and sexual differences (Killiaridis et al., 1995) and also the phase of the dentition, location of the bite force, emotional aspects of the patient as well as the attitude of the researcher and the patient, signals and symptoms of temporomandibular dysfunction(Fields et al., 1986; Bakke et al., 1990).

The measure of the maximum bite force is an attempt to quantify the total force of the muscles of mandibular closeness (Wang et al., 1990). Castro folio et al. (2005) concluded that the variables of the surface electromyography measured in the isometric contraction of the lifter mandibular muscles with the recording of the bite force showed good reproducibility to clinical application, denoting the importance of the knowledge that the reception of load in the left and right during the mandibular opening and closing in the isometric bite, the head of the mandible of the balancing side receives, in average, more load than the head of the mandible in the side of work that depends on the pattern of muscular recruiting (if the bite point stays constant) and the mechanical properties of the food (Hylander, 1975, 1977, 1985).

The aim of this study was to examine in individuals considered healthy, the activity pattern of the masseter and anterior portion of both left and right sides, respectively, with the maximum bite force.

\section{Material and Method}

The study consisted in the selection of seventeen volunteers, from both genders, connected to the School of Dentistry of Piracicaba, with average age of 25. The current work started only after the approval of the Ethical Committee in Research with Human Beings (CEP), of FOP-UNICAMP, according to documentation required by the Resolution 196/96 of the National Commission of Ethics in Researches (CONEP) of the National Council of Health. For the selection of the sample of the current study, the criteria that were followed are: dental relation of Class I of Angle and permanent dentition, no functional orthodontic and/or orthopedic treatment of the maxilla in the last 10 years, no occurrence of large cavities and no apparent signals or symptoms of masticator disorders.

The electromyography records were obtained from the masseter muscle and the anterior portion of the temporal muscle. It was used the Electromyography EMG-800C of EMG System of Brazil Ltd. of eight channels, with five bands 
tado a un ordenador PC mediante un convertidor de red Ethernet $10 \mathrm{Mb}$ con un conector RJ45 (10BASE T) y utilizaba el protocolo TCP/IP. El filtro era de tipo Butterworth, con un paso de banda inferior de $500 \mathrm{~Hz}$ y paso de banda superior de $20 \mathrm{~Hz}$. El programa informático de adquisición y análisis de las señales electromiográficas era para un sistema operativo Windows XP/98/NT. Presentaba simultáneamente las señales de varios canales y los resultados del procesamiento de la señal (valores RMS medio, mínimo, máximo y desviación estándar, FFT en línea), con una frecuencia de adquisición (muestreo) de hasta 4800 muestras/segundo por canal programable. Se utilizaron electrodos de superficie bipolares pasivos para niños, de $\mathrm{Ag} / \mathrm{AgCl}$, de forma circular y descargables de Meditrace ${ }^{\circledR}$ Kendall-LTP, Chicopee modelo MA01. Estos captan la actividad eléctrica de varias unidades motoras y a la vez están conectados a un pre-amplificador con una ganancia de 20x, que detecta el funcionamiento general de la dinámica muscular. Se colocó el electrodo de referencia (tierra) en la muñeca derecha, untada con gel electroconductivo, para reducir el ruido eléctrico indeseado de la señal electromiográfica. Los electrodos de superficie se fijaron bilateralmente a la porción anterior del músculo temporal y a la parte superficial del músculo masetero, según puntos de referencia anatómicos y utilizando los procedimientos descritos por Vitti y Basmajian (1997). Tras esta selección, las señales fueron procesadas con el programa informático EMG Analysis V1.01 de EMG System of Brazil, Ltd., que determinaba el valor de RMS durante la mordedura isométrica y la mordedura de fuerza máxima en kilogramos de fuerza (Kgf).

La fuerza de mordedura se determinó con un transductor de presión que era un tubo de goma conectado a un sensor de presión (MPX 5700) (Motorola SPS, Austin, TX, EE.UU.). El tubo y el sensor se conectaban a un convertidor analógico/circuito digital electrónico, que se alimentaba por una señal analógica procedente de un elemento presosensible. El sistema se conectaba a una computadora con un programa BASIC para la interpretación de la fuerza de mordedura. Este programa informático genera un archivo de texto que tabula los datos de la fuerza de mordedura que se puede leer en Excel.

Se realizaron tres evaluaciones de la fuerza de mordedura en cada voluntario, que mordió el tubo aplicando la máxima fuerza tres veces sucesivamente, cada vez durante 5 segundos, y separadas por intervalos de 1 minuto. El tubo se colocaba entre los molares superiores e inferiores de ambos lados. Para obtener la intercuspidación máxima, los voluntarios recibieron entrenamiento antes de trabajar con el dispositivo.

Se calcularon los valores numéricos de cada evaluación, obteniendo la diferencia entre las presiones máxima y mínima y el valor promedio de las tres mediciones para cada paciente seleccionado. Las lecturas obtenidas con el tubo de registro de presión se transferían al programa Excel para su conversión a libras por pulgada cuadrada (PSI) y después a Newtons (N) en función de la superficie del tubo (1 PSI = 29.792).

Durante ambas fases del estudio, la grabación electromiográfica y la adquisición de la fuerza de mordedura, los voluntarios permanecían sentados y con la cabeza inmovilizada en un plano de Frankfurt. of amplification gain, rejection of common mode $>120 \mathrm{~dB}$, analogical-digital converter $(A / D)$ of 16 bits of resolution of dynamic band, connected to PC using a net converter Ethernet $10 \mathrm{Mbits}$ with a connector RJ45 (10BASE T) utilizing protocol TCP/IP; filter type Butterworth, of low-pass of $500 \mathrm{~Hz}$ and high-pass of $20 \mathrm{~Hz}$; software of acquisition and analysis of electromyographic signals platform Windows XP/ 98 / NT for simultaneously presentation of the signals of various channels and treatment of the signal (value of RMS, medium, minimum, maximum and desvio padrão, FFT on line) with rate of acquisition (sampling) up to 4800 samples / second per programmable channel per software. It was used passive bipolar surface electrodes for kids of $\mathrm{Ag} / \mathrm{AgCl}$, circular format and dischargeable of Meditrace ${ }^{\circledR}$ KendallLTP, model Chicopee MA01, which capture the electrical activity of various motor units, at the same time attached to a pre amplifier with gain of 20 times, supplying a general performance of the muscular dynamics. A reference electrode (earth) was positioned in the right wrist greased with electro conductor gel to reduce the unwanted electrical noises to the electromyographic signal. Surface electrodes were fixed, bilaterally, in the anterior portion of the temporal muscle, superficial portion of the masseter muscle, according to anatomical references and procedures according to Vitti e Basmajian (1997). After this selection, the signal were processed through the software EMG Analysis V1.01 of EMG System of Brazil Ltd., which determine the value of the RMS in isometric and the maximum bite force in Kilogramforce(Kgf).

The bite force was determined with a pressurized transductor which consists of a pressurized rubber tube connected to a sensor element (MPX 5700)*. The tube and the sensor were connected to an analogical converter / electronic digital circuit, fed by an analogical signal coming from an element of sensitive pressure. The system was connected to a computer and the software to read the bite force was developed in Basic language. This software generates a text file in column with the data of the bite force easily read by Excel.

Three evaluations of the bite force were operated in each volunteer, who bit the tube with maximum force three times successively for 5 seconds, with an interval of 1 minute. The tube was placed among the superior and inferior molar teeth, bilaterally. To obtain the maximum intercuspidation, the volunteers were trained before the operation of the device.

The numeric values of each evaluation were calculated by the difference between maximum and minimum pressure and the average value of the three takes, for each patient selected. The values of the pressurized tube were transferred to the software Excel where were obtained in pounds per square inch ( $p$ si) and later converted in Newtons(N) taking in consideration the area of the tube ( 1 psi= 29 792).

For both, the eletromyographic records and the acquisition of the bite force, the volunteers were kept seated, with the Plan of Frankfurt. 


\section{Análisis estadístico}

Para comparar cuantitativamente la contribución de los maseteros y de la porción anterior de los músculos temporales a la fuerza de mordedura, se calculó el promedio del masetero y de los músculos temporales derecho e izquierdo en cada voluntario. El índice de actividad (Naeije y cols., 1989) se utilizó para delimitar la contribución relativa del masetero y del temporal durante la intercuspidación máxima:

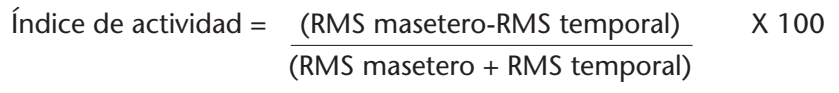

El índice de actividad varía entre +100 y -100

- Actividad aislada de los músculos maseteros

- Actividad equivalente de ambos músculos

- Actividad aislada de los músculos temporales

Para describir cuantitativamente la asimetría de la actividad de los músculos masticadores, se utilizó el índice de asimetría, que es equivalente matemáticamente al índice de actividad:

Índice de asimetría $=\frac{\text { (RMS derecho-RMS izquierdo) }}{\text { (RMS derecho + RMS izquierdo) }} \times 100$

El índice de asimetría también varía de +100 a -100

- Actividad aislada del músculo derecho

- Actividad equivalente de ambos lados

- Actividad aislada del músculo izquierdo

Los análisis estadísticos realizados eran la correlación lineal, la prueba $t$ aparejada y el análisis de la varianza. La probabilidad de $p<0,05$ se consideró estadísticamente significativa.

\section{Resultados}

La tabla 1 resume los valores promedios de la actividad electromiográfica de los cuatro músculos masticadores en la posición postural y en la posición de apertura máxima de la boca entre hombres y mujeres. En reposo, se encontró una diferencia estadísticamente significativa únicamente en el músculo masetero derecho, cuyo potencial eléctrico era mayor en varones. En la tarea de intercuspidación máxima, se encontró también una diferencia estadísticamente significativa para el músculo masetero derecho en varones (Tabla 1).

El índice de asimetría se calculó para cuantificar las diferencias entre los lados derecho e izquierdo de cada voluntario. No se encontró dimorfismo sexual al analizar los datos con la prueba $t$ de Student para muestras independientes, siendo calculado por el índice total de asimetría (Tabla 2). Al considerar los músculos masetero y temporal anterior, el masetero presentó un mayor índice de asimetría en las tareas realizadas.

\section{Statistical Analysis}

In order to quantitatively compare the contribution of the masseter and anterior portion of the temporal muscles in the bite force, the average of the masseter and temporal muscles, right and left, respectively were calculated in each volunteer. The activity index (Naeije et al., 1989) was used to indicate the relative contribution of the masseter and temporal in maximum intercuspidation :

$$
\begin{aligned}
\text { Activity Index }= & \text { (RMS masseter-RMS temporal) } \\
& \text { (RMS masseter }+ \text { RMS temporal })
\end{aligned}
$$

$\times 100$

The Activity Index varies between +100 and -100

- Activity of the masseter muscles only $\quad+100$

- Equal activity of the muscles 0

- Activity of the temporal muscles only $\quad-100$

To quantitatively describe the asymmetry in the activity of the masticator muscles, the asymmetry index was followed which is mathematically equivalent to the activity index:

$$
\text { Asymmetry Index }=\frac{\text { RMS right }- \text { RMS left }}{\text { RMS right }+ \text { RMS left }} \quad \times 100
$$

The asymmetry index also varies from $+100 e-100$

- Activity of the right muscle only $\quad+100$

- Equal activity 0

- Activity of the left muscle only $\quad-100$

The statistical tests used were of linear correlation, pared test $t$ and analysis of variance. Probability of $p<0,05$ were considered statistically significant.

\section{Results}

The table 1 registered the average values of the electromyographic activity of four masticator muscles in postural position and maximum aperture between the male and female genders. In resting there was significant statistical difference only for the right masseter muscle, being the electrical potential higher for the male gender. In the task of maximum intercuspidation, there was significant statistical difference also for the right masseter muscle in the male gender (Table 1).

The Asymmetry Index was calculated to quantify the differences between the right and left sides of each volunteer. There was not sexual dimorphism tested by the test $t$ of Student for independent samples, being calculated the total Asymmetry Index (Table 2). Considering the masseter and anterior temporal muscles, the first presented asymmetry index higher on both tasks performed. 
Tabla 1. Valores de la media, en microvoltios, desviación estándar (DE) y prueba de Student para muestras independientes de los potenciales eléctricos registrados en los músculos masetero (MM) y temporal anterior (AT) de los lados derecho (R) e izquierdo (L), en reposo y durante la mordedura máxima, en ambos sexos

\begin{tabular}{|c|c|c|c|c|c|c|}
\hline & \multicolumn{2}{|c|}{ Mujeres } & \multicolumn{2}{|c|}{ Hombres } & \multicolumn{2}{|c|}{ T de Student } \\
\hline & Media & $\mathrm{DE}$ & Media & DE & $\mathbf{t}$ & $\mathbf{P}$ \\
\hline \multicolumn{7}{|c|}{ Reposo } \\
\hline AT R & 3,57 & 5,12 & 4,49 & 3,2 & 2,14 & ns \\
\hline AT L & 5,34 & 1,66 & 3,39 & 1,34 & 2,77 & ns \\
\hline MM R & 2,88 & 0,34 & 3,46 & 1,67 & 2 & $p<0,05$ \\
\hline MM L & 2,45 & 0,26 & 2,84 & 1,01 & 2,14 & ns \\
\hline \multicolumn{7}{|c|}{ Mordedura máxima } \\
\hline AT R & 148,51 & 66,64 & 101,97 & 26,02 & 2,57 & ns \\
\hline AT L & 73,38 & 15,57 & 108,14 & 34,77 & 2,13 & ns \\
\hline MM R & 131,05 & 44,94 & 147,14 & 68 & 2,2 & $p<0,01$ \\
\hline MM L & 153,79 & 42,26 & 150,64 & 61,51 & 2,2 & ns \\
\hline
\end{tabular}

Table 1. Medium values in $u V$, deviation-standar (ds) and Student test for independent samples of the electric potentials registered in the masseter muscles (MM) and anterior portion temporal (AT) of the sides right $(R)$ and left $(L)$ in the rest and maximum bite for both sexes

\begin{tabular}{|c|c|c|c|c|c|c|}
\hline & \multicolumn{2}{|c|}{ Female } & \multicolumn{2}{|c|}{ Male } & \multicolumn{2}{|c|}{ Student's $t$} \\
\hline & Mean & sd & Mean & sd & $t$ & $P$ \\
\hline \multicolumn{7}{|l|}{ Rest } \\
\hline$A T R$ & 3.57 & 5.12 & 4.49 & 3.2 & 2.14 & ns \\
\hline$A T L$ & 5.34 & 1.66 & 3.39 & 1.34 & 2.77 & ns \\
\hline$M M R$ & 2.88 & 0.34 & 3.46 & 1.67 & 2 & $p<0.05$ \\
\hline$M M L$ & 2.45 & 0.26 & 2.84 & 1.01 & 2.14 & $n s$ \\
\hline \multicolumn{7}{|c|}{ Maximal bite } \\
\hline$A T R$ & 148.51 & 66.64 & 101.97 & 26.02 & 2.57 & ns \\
\hline$A T L$ & 73.38 & 15.57 & 108.14 & 34.77 & 2.13 & ns \\
\hline$M M R$ & 131.05 & 44.94 & 147.14 & 68 & 2.2 & $p<0.01$ \\
\hline$M M L$ & 153.79 & 42.26 & 150.64 & 61.51 & 2.2 & ns \\
\hline
\end{tabular}

\section{Actividad del masetero y porción anterior del músculo temporal}

La tabla 3 resume los registros del índice de actividad de los músculos masetero y temporal para las tareas de reposo e isometría. En la posición en reposo, más del $58 \%$ de los voluntarios mantuvo la posición mandibular utilizando la porción anterior del músculo temporal más que el músculo masetero. La acción promedia de la porción anterior del músculo temporal fue mayor que la del músculo masetero (23,59\% frente al 6,38\%). El músculo masetero presentó una mayor actividad de intercuspidación (más del 77\%) que la porción anterior del músculo temporal.

La contribución relativa del masetero y de la porción anterior de los músculos temporales dependió del nivel de contracción $(p<0,05)$. Una mayor fuerza de mordedura reflejó una mayor contribución del músculo masetero (Fig. 1).

\section{Discusión}

El estudio actual ha investigado la variabilidad normal de la actividad de los músculos masticadores, su asimetría y sus contribuciones respectivas a generar la fuerza máxima de mordedura.
Activity of the masseter and anterior portion of temporal muscles

The table 3 indicated the record of the activity index of the masseter and temporal muscles for the tasks of resting and isometry. In the resting position more than $58 \%$ of the volunteers kept the mandibular position utilizing thee anterior portion of the temporal muscle more than the masseter muscle. The action of the anterior portion of the temporal muscle in average was higher than the masseter muscle (23.59\% versus $6.38 \%)$. The masseter muscle presented a higher activity in the dental intercuspidation (more than $77 \%$ ) than the anterior portion of the temporal muscle.

The relative contribution of the masseter and anterior portion of the temporal muscles depended on the contraction level $(p<0.05)$. A bigger bite force showed higher contribution of the masseter muscle (Fig. 1).

\section{Discussion}

The current study has investigated the normal variability of the activity of the masticator muscles, its asymmetries 
El índice de asimetría y la actividad muscular han sido propuestos para evaluar a pacientes con alteraciones musculares craniomandibulares (Naeije y cols., 1985). Las investigaciones han demostrado que la actividad muscular asimétrica depende de la fuerza de mordedura y que, a cada nivel de contracción, la asimetría del músculo masetero es mayor que la porción anterior del músculo temporal (Naeije y cols., 1989; Pruim, 1979; Ferrario y cols., 1993), que coincide con los resultados de este estudio.

Se observó dimorfismo sexual en la actividad eléctrica del masetero derecho en las tareas de reposo y mordedura máxima, que era mayor en varones. Las diferencias craneales entre sexos constan sobre todo de una mayor debilidad de estos músculos en mujeres, que condiciona el menor desarrollo de los huesos (Madeira, 1998; Rizzolo y Madeira, 2004). Throckmorton y Dean (1994) han demostrado que la ventaja mecánica del masetero en varones y la fuerza de mordedura son mayores, una diferencia que podría atribuirse al tamaño de la sección transversal del músculo.

Los voluntarios participantes en este estudio presentaron un índice de asimetría menor en la posición postural ($11,4 \%)$ que en la isométrica (14,6\%). El músculo temporal anterior evidenció un índice de asimetría menor que el masetero en la posición postural. Durante la mordedura máxima, el predominio que mostraba el músculo temporal anterior a una intensidad de contracción baja pasa a un aumento de la contribución del masetero a la fuerza máxima de mordedura (Naeije y cols., 1989; McCarroll y cols., 1989a; McCarroll y cols., 1989b). Esta dinámica mandibular también coincide con los hallazgos de Throckmorton y Dean (1994), Latif (1957) y Bérzin (2004).

Hylander (1975, 1977, 1985) ha demostrado la importancia de analizar la biomecánica mandibular en una proyección frontal, comunicando que los músculos de oclusión en el lado de trabajo generan más fuerza muscular que los del lado de balanceo, que reciben una carga mayor. Por otra parte, se cuestiona las diferencias en los registros electromiográfi-
Tabla 2. La media, desviación estándar (DE) y error estándar (EE) del índice de asimetría de las actividades eléctricas de los músculos masetero (MM) y temporal anterior (AT)

$\begin{array}{lccc} & \text { Media } & \text { DE } & \text { EE } \\ \text { Reposo } & & & \\ \text { MM } & 11,4 & 10,59 & 3,74 \\ \text { AT } & 6,75 & 38,45 & 12,81 \\ \text { Mordedura máxima } & & & \\ \text { MM } & 14,6 & 27,05 & 9,02 \\ \text { AT } & 10,24 & 20,34 & 7,15 \\ \text { ns: no significativo }(p>0,05) \text {. } & & \\ & & & \end{array}$

Table 2. Mean, standard deviation ( $s d$ ) and standard error (se) of the Index of Asymmetry of the electric activities of the masseter muscle (MM) and anterior temporal muscle (AT)

$\begin{array}{lccc} & \text { Mean } & \text { SD } & \text { SE } \\ \text { Rest } & & & \\ \text { MM } & 11.4 & 10.59 & 3.74 \\ A T & 6.75 & 38.45 & 12.81 \\ \text { Maximal bite } & & & \\ \text { MM } & 14.6 & 27.05 & 9.02 \\ \text { AT } & 10.24 & 20.34 & 7.15\end{array}$

ns: no significative $(p>0,05)$.

Tabla 3. Los índices de actividad muscular en las posiciones de reposo y de mordedura máxima. Valores de la media, desviación estándar (DE) y error estándar (EE) de los músculos masetero (MM) y temporal anterior (AT)

\begin{tabular}{|c|c|c|c|c|c|}
\hline & $\mathbf{n}$ & $\%$ & Media & $\mathrm{DE}$ & $\mathrm{EE}$ \\
\hline \multicolumn{6}{|l|}{ Reposo } \\
\hline $\mathrm{MM}>\mathrm{AT}$ & 7 & 35,29 & 6,38 & 5,72 & 2,33 \\
\hline $\mathrm{AT}>\mathrm{MM}$ & 10 & 58,82 & 23,59 & 18,75 & 5,93 \\
\hline \multicolumn{6}{|c|}{ Mordedura máxima } \\
\hline $\mathrm{MM}>\mathrm{AT}$ & 13 & 77,47 & 20,92 & 19,02 & 5,49 \\
\hline $\mathrm{AT}>\mathrm{MM}$ & 4 & 23,53 & 7,31 & 5,3 & 2,65 \\
\hline
\end{tabular}

Table 3. Indexes of muscular activity for rest position and maximum bite. Values of the mean, the deviate standard (se) and standard error (ep) of the muscles masseter (MM) and anterior temporal muscle (AT)

$\begin{array}{lccccc} & n & \% & \text { Mean } & \text { SD } & \text { SE } \\ \text { Rest } & & & & & \\ M M>A T & 7 & 35.29 & 6.38 & 5.72 & 2.33 \\ A T>M M & 10 & 58.82 & 23.59 & 18.75 & 5.93 \\ \text { Maximum bite } & & & & & \\ M M>A T & 13 & 77.47 & 20.92 & 19.02 & 5.49 \\ A T>M M & 4 & 23.53 & 7.31 & 5.3 & 2.65\end{array}$

number of individual; \%: percent of individual. as well as its contributions to generate maximum bite force.

The Asymmetry Index and Muscular Activity were proposed to evaluate patients with muscular craniomandibular disorders (Naeije et al., 1985). Researches showed that the asymmetric muscular activity depended on the bite force and that in each level of contraction the asymmetry of the masseter muscle is higher than the anterior portion of the temporal muscle, being in accordance to (Naeije et al., 1989; Pruim, 1979; Ferrario et al., 1993); corroborating with the results found in this study. There was sexual dimorphism in the electrical activity of the masseter muscle in the right side in both tasks of resting and maximum bite, being higher in the male gender, once the sexual difference of the cranium mainly refer to the female fragility of the muscles, determining a lower development of the bone superstructures in women (Madeira, 1998; Rizzolo \& Madeira, 2004). Throckmorton \& Dean (1994) Showed that the mechanical advantage of the masseter muscle in individuals of male gender was higher, as well as the bite force, whose difference could be explained by the size of the transversal section of the muscle.

The volunteers of this essay presented an asymmetric index lower in postural position $(-11,4 \%)$ than in isometry $(14,6 \%)$. The anterior temporal muscle showed an asymmetry index lower than the masseter muscle in the postural position. In the maximum bite, the prevalence of the anterior temporal muscle 
cos de los músculos masticadores de ambos lados con relación a la fuerza máxima de mordedura, es decir, a la capacidad del individuo de reclutar a todas las unidades motoras. Los criterios de asimetría para elaborar y comparar el proceso diagnóstico parecen ser útiles. Según los resultados de Ferrario y cols. (1993), el índice de asimetría de 18\% puede considerarse normal.

\section{Conclusiones}

Puede considerarse normal cierto grado de asimetría muscular, que difiere entre el masetero y la porción anterior del músculo temporal y depende de la tarea realizada o de la intensidad de contracción. El índice de asimetría fue menor en la posición postural que en la de abertura oral máxima. El tratamiento interdisciplinar por la deontología, fonoterapia y fisioterapia no se resume únicamente en un "aspecto simétrico" cuando los tejidos del aparato estomatognático son capaces de adaptarse a su entorno regional debido a las reacciones de los tejidos a los estados de salud o de disfunción.

\section{Bibliografía}

1. Helkimo E, Carlsson GE, Helkimo M. Bite force and state of dentition. Ata Odontol Scand 1977;35:297-303.

2. Bakke M, Moller E. Distortion of maximal elevator activity by unilateral premature tooth contact. Scand J Dent Res 1980;88:67-75.

3. Killiaridis S, Johansson A, Haraldson T, Omar R, Carlsoon GE. Craniofacial morphology, occlusal traits, and bite force in persons with advance occlusal tooth wear. Am J Orthod Dentofacial Orthop 1995;107:286-92.

4. Fields HW, Proffit WR, Case JC, Vig KW. Variables affecting measurements of vertical occlusal. Scand J Dent Res 1986;65:135-8.

5. Bakke $M$, Holm B, Jensen BL, Michler L, Moller E. Unilateral, isometric bite force en 8-68-yerar-old women and men related to occlusal factors. Scand J Dent Res 1990;98:149-58.

6. Wang K, Arima T, Arendt-Nielsen L, Svensson P. EMG-force relationships are influenced by experimental jaw-muscle pain. J Oral Rehabil 2000;27:394-402.

7. Castroflorio T, Icardi K, Becchino B, Merlo E, Debernardi C, Bracco P, Farina D. Reproducibility of surface EMG variables in isometric sub-maximal contractions of jaw elevator muscles. J Electromyogr Kinesiol 2006;16:498-505. Epub 2005 Nov 15.

8. Hylander WL. The human mandible: lever or link? Am J Phys Anathropol 1975; 43:227-42.

9. Hylander WL. In vivo bone strain in the mandible of Galago crassicaudatus. Am J Phys Anthrop 1977;46:309-26.

10. Hylander W. Mandibular function and temporomandibular joint loading. In Carlson DS y cols. Developmental aspects of temporomandibular joint disorders. Ann Harbor: Center of Human growth and development 1985;p.19-35. with low level of contraction is according to (Naeije et al., 1989; McCarroll et al., 1989a; McCarroll et al., 1989b) where the masseter muscle increases its contribution in the maximum bite force. This mandibular dynamics also is in accordance to the findings of Throckmorton \& Dean (1994), Latif (1957), Bérzin (2004).

Hylander (1975, 1977, 1985) demonstrated the importance in analyzing the mandibular biomechanics in frontal projection, reporting that the muscles of occlusion in the side of the job generate more muscular force than the side of balancing which receive more load. On the other hand, differences in the electromyographic records of the masticator muscles of both sides is questioned in their relation to the maximum bite force, that is, the capacity of the individual in recruiting all the motor units. The criteria of asymmetry to elaborate and compos the process of diagnosis seems to be useful and according to the results of Ferrario et al.(1993), an asymmetry index of 18\% can be considered normal.

\section{Conclusion}

A certain degree of muscular asymmetry can be considered normal which is different to the masseter and anterior portion of temporal muscles and depends on the task performed or contraction level. The asymmetry index was lower in postural position than in maximum aperture. The interdisciplinary treatment among deontology, speech therapy and physical therapy don't have to be only "symmetrical appearance", once the tissues of the stomatognatic system are capable of adapting to their regional environment due to tissue responses in condition of health or in dysfunction. 
11. Naeije M, McCarroll RS, Weijs WA. Electromyographic activity of the human masticator muscles during sub maximal clenching in the intercuspal position. J Oral Rehab 1989;16:63-70.

12. Pruim, G]. Asymmetries of bilateral static bite forces in different locations on the human mandible. J Dental Res 1979;58:1685-7.

13. Ferrario VF, Sforza C, Miani Jr, D'Addona A, Barbini E. Electromyographic activity of human masticatory muscles in normal young people. Statistical evaluation of reference values for clinical applications. J Oral Rehab 1993;20:271-80.

14. McCarroll RS, Naeije M, Kim YK, Hansson TL. The immediate effect of splint induced changes in jaw positioning on the asymmetry of submaximal masticatory muscle activity. J Oral Rehabil 1989;16:16370.

15. McCarroll RS, Naeije M, Kim YK, Hansson TL. Short term effect of a stabilization splint on the asymmetry of sumaximal masticatory muscle activity. J Oral Rehabil 1989;16:171-6.

16. Throckmorton GS, Dean JS. The relationship between jaw -muscle mechanical advantage and activity levels during isometric bites in humans. Archs Oral Biol 1994;39:429-437.

17. Madeira MC. Anatomia da face: bases anátomo-funcionais para a prática odontológica. 2.ed. São Paulo: Sarvier 1998.

18. Rizzolo RJ, Madeira MC. Anatomia Facial com fundamentos de anatomia sistêmica geral. São Paulo: Sarvier; 2004.

19. Latif A. An electromyographic study of temporalis muscle in normal person during selected positions and movements of the mandible. Am J Orthod 1957;43: 577-91.

20. Bérzin F. Surface electromyography in the diagnosis of syndromes of the cranio-cervical pain. Braz J Oral Sci 2004;3:484-91. 